\title{
TRANSFORMASI \\ MENUJU MADRASAH BERMUTU TERPADU
}

Novan Ardy Wiyani

Dosen Jurusan PGSD STKIP Islam Bumiayu

\begin{abstract}
The growth of madrasah in Indonesian homeland is the result of pull of the pesantren as native Indonesian educational institutions (conventional) that are already on one side with a western education (modern) on the other. In the colonial period, in accordance with the mission of colonialism, madrasah are so marginalized and made a variety of colonial government policies that marginalize the madrasah. One impact is still visible from the discriminatory policy is madrasah experienced a variety of management weaknesses. Under these circumstances, management weaknesses indicated by the closed nature and is not oriented to the outside so that the madrasah was a slow progression and even static. To overcome this, one of the rescue efforts that can be taken by the stakeholders of education in the madrasah is to change the paradigm of conventional management on the quality of madrasah into an integrated paradigm. This paper describes the transformation towards integrated quality of madrasah. The author conducted an analysis of integrated quality management theory and then demonstrate its application in the field of Islamic education can do madrasah to get a quality education services.

Key world: Grow of madrasah anf integrated quality management.
\end{abstract}

\section{Pendahuluan}

Indonesia merupakan negara penghutang atau debitor nomor 6, negara terkorup nomor 3, peringkat Sumber Daya manusia (SDM) ke 112 dari 127 negara dengan penduduk yang hidup di bawah garis kemiskinan mencapai $30 \%$ dan pengangguran terbuka mencapai 12 juta (E. Mulyasa, 2009: 3). Ketika angka pengangguran meningkat, lembaga pendidikan pun selalu menuai badai tudingan masyarakat dan dunia kerja karena tidak mampu melahirkan lulusan yang bermutu (Sudarwan Danim, 2008: 10). Itulah tantangan lembaga pendidikan dalam memasuki millennium development goal, yaitu era globalisasi sebagai era persaingan mutu atau kualitas. 
Globalisasi yang ditandai oleh adanya mega kompetisi dalam segala aspek kehidupan semakin terasa sulit untuk dapat dihindari. Konsekuensinya, lembaga pendidikan di Indonesia dituntut dapat menghasilkan lulusan yang memiliki kompetensi tinggi. Lulusan lembaga pendidikan Islam, terutama madrasah tanpa mendapatkan SDM bermutu sulit untuk memenangkan kompetisi dalam era globalisasi ini (Sutrisno, 2010: 224). Hal ini yang menjadikan mutu sebagai satu-satunya target yang sangat penting dalam dunia pendidikan.

Manajemen mutu terpadu merupakan sarana yang memungkinkan untuk dapat beradaptasi dalam era globalisasi dengan cara yang positif dan konstruktif (Jerome S Arcaro, 2007: 2). Pendidikan Islam harus merubah paradigmanya. Norma-norma dan keyakinan-keyakinan yang lama harus dipertanyakan. Pendidikan Islam yang hanya menekankan pada dimensi normatif-teologis juga tidak akan banyak memberikan konstribusi dalam memecahkan persoalan-persoalan empiris sosiologis yang terjadi dalam kehidupan masyarakat kontemporer (M. Agus Nuryatno, 2010: 202). Oleh karena itu, pendidikan Islam perlu memberikan sentuhan-sentuhan transformasi bagi madrasah untuk mengimplementasikan manajemen mutu terpadu. Dengan menghubungkan dan mendialogkan pendidikan Islam dengan manajemen mutu terpadu diharapkan bisa terwujud madrasah bermutu terpadu.

\section{Profil Madrasah dari Masa ke Masa}

Istilah madrasah sebagai nama untuk menyebut lembaga pendidikan Islam sudah muncul sejak awal perkembangan peradaban Islam berhasil melintasi teritori Semenanjung Arabia. Dalam catatan sejarah, madrasah pernah menjadi lembaga pendidikan par excelence di dunia Islam karena kedudukannya yang sedemikian prestisius di mata umat Islam. Melalui madrasah, dinamika intelektual-keagamaan mencapai puncaknya. Kemunculan madrasah dipandang oleh para sejarawan pendidikan sebagai salah satu bentuk pembaharuan pendidikan Islam di Indonesia.

Pembaharuan pendidikan Islam di Indonesia dalam bentuk madrasah tersebut dilatarbelakangi oleh dua faktor penting, yaitu; Pertama faktor intern, kondisi masyarakat muslim Indonesia yang terjajah dan terbelakang dalam dunia pendidikan mendorong semangat beberapa orang pemuka- 
pemuka masyarakat Indonesia untuk memulai gerakan pendidikan Islam tersebut. Kedua, faktor ekstern, yakni sekembalinya pelajar dan mahasiswa Indonesia yang menuntut ilmu agama ke timur tengah, dan setelah mereka kembali ke Indonesia mereka memulai gerakan-gerakan pembaharuan dalam bidang pendidikan.

Sebenarnya pertumbuhan madrasah tidak hanya atas dasar semangat pembaharuan dikalangan umat Islam, tetapi bertumpu pada dua faktor: Pertama, pendidikan Islam (masjid dan pesantren) dianggap kurang sistematis dan kurang memberikan kemampuan pragmatis yang memadai. Kedua, perkembangan sekolah-sekolah Belanda di kalangan masyarakat cenderung meluas dan membawa watak sekularisme, sehingga harus diimbangi dengan sistem pendidikan Islam yaitu madrasah yang memiliki model dan organisasi yang lebih teratur dan terencana. Jadi, pertumbuhan madrasah sekaligus menunjukan adanya dua pola respons umat Islam yang lebih progresif, tidak semata-mata pasif terhadap politik pendidikan Belanda (Mahmud Arif, 2010: 145).

Pendek kata, pertumbuhan madrasah di tanah air adalah hasil tarik menarik antara pesantren sebagai lembaga pendidikan indegenous Indonesia (tradisional) yang sudah ada di satu sisi dengan pendidikan Barat (modern) di sisi lain (Abdul Racman Saleh, 2004: 12). Pada masa penjajahan, sesuai dengan misi kolonialisme, madrasah begitu dianaktirikan. Madrasah dikategorikan sebagai sekolah liar bahkan pemerintah kolonial telah memproduk peraturan-peraturan yang membatasi atau justru mematikan sekolah-sekolah partikulir termasuk madrasah dengan mengeluarkan peraturan yang disebut Wilde Schoolen Ordonatie tahun 1933.

Sebelum terbit peraturan tersebut, pemerintah kolonial juga mengeluarkan peraturan yang dikenal dengan "Ordonansi Guru" pada tahun 1905 dan 1925 yang menyebutkan bahwa izin tertulis untuk mengajar harus diberlakukan kepada Islam. Ordonansi itu secara khusus dimaksudkan untuk membatasi aktivitas guru-guru madrasah yang pada dasarnya ditujukan untuk menghambat kemajuan Islam. Dampak dari kebijakan yang diskriminatif tersebut, madrasah sampai saat ini menghadapi kesulitan-kesulitan dan terisolasi dari arus modernisasi sehingga profil madrasah saat ini dapat diamati sebagai berikut: 


\section{Novan Ardy Wiyani}

1. Madrasah terpinggirkan dari arus modernisasi. Kondisi ini menjadikan madrasah cenderung pada sifat ketertutupan dan ortodoksi. Pada umumnya madrasah terlambat dalam merespon modernisasi dibandingkan dengan lembaga-lembaga pendidikan umum.

2. Karena kebijakan yang sangat diskriminatif dari pemerintah kolonial, madrasah terkondisikan menjadi milik rakyat pinggiran atau pedesaan. Madrasah pun mempunyai konotasi sebagai pendidikan "kampungan" yang lekat dengan keterbelakangan dan sangat ortodoks karena memang kawasan pedesaan dengan kondisi masyarakatnya yang agraris yang sebagian besar ekonominya lemah dan kurang menguasai teknologi menyebabkan madrasah secara struktural bersifat local oriented.

3. Muatan kurikulum madrasah cenderung pada praktik-praktik keagamaan dan kurang memperhatikan ilmu pengetahuan dan teknologi. Isi pendidikan di madrasah masih bercorak dualistis sehingga antara pembelajaran ilmu keagamaan dengan ilmu pengetahuan umum belum terpadukan dikarenakan ilmu keagamaan masih begitu normatif, sedangkan pembelajaran ilmu umum terkesan sekuler.

4. Madrasah mengalami berbagai kelemahan manajemen meskipun tidak seluruhnya harus dianggap sesuatu yang negatif. Dalam keadaan ini, kelemahan manajemen ditunjukkan oleh sifatnya yang tertutup dan tidak berorientasi ke luar sehingga perkembangan madrasah pun menjadi lamban bahkan statis (H.A.R. Tilaar, 2000: 170).

Untuk mengatasi hal ini, salah satu upaya penyelamatan yang dapat ditempuh oleh para stakeholders pendidikan di madrasah adalah dengan merubah paradigma manajemen konvensional pada madrasah menjadi paradigma madrasah bermutu terpadu.

\section{Madrasah Bermutu Terpadu}

Program mutu sebenarnya berasal dari dunia bisnis. Dalam dunia bisnis, baik yang bersifat produksi maupun jasa, program mutu merupakan program utama sebab kelanggengan dan kemajuan usaha sangat ditentukan oleh mutu sesuai dengan permintaan dan tuntutan pengguna. Permintaan dan tuntutan pengguna terhadap produk dan jasa layanan terus berubah dan berkembang. Sejalan dengan hal itu, mutu produk dan jasa layanan 
yang diberikan harus selalu ditingkatkan. Hal tersebut dikarenakan dewasa ini mutu bukan hanya menjadi masalah dan kepedulian dalam bidang bisnis melainkan juga dalam bidang-bidang lainnya, seperti layanan sosial, bidang keamanan dan ketertiban, serta pendidikan (Nana Syaodih Sukmadinata, $2006: 8$ ). Secara umum mutu adalah gambaran dan karakteristik menyeluruh dari barang atau jasa yang menunjukkan kemampuannya dalam memuaskan kebutuhan yang diharapkan.

Dalam konteks pendidikan Islam, pengertian mutu mencakup input, proses dan output pendidikan. Input pendidikan adalah segala sesuatu yang harus tersedia karena dibutuhkan untuk berlangsungnya proses. Sesuatu yang dimaksud berupa sumber daya dan perangkat lunak serta harapanharapan sebagai pemandu bagi berlangsungnya proses. Input sumber daya meliputi kepala madrasah, guru, karyawan, peserta didik, peralatan, perlengkapan, uang, bahan dan lain sebagainya.

Input perangkat lunak meliputi struktur organisasi madrasah, peraturan perundang-undangan, deskripsi tugas, rencana, program dan lain sebagainya. Input harapan-harapan berupa visi, misi, tujuan, dan sasaran-sasaran yang ingin dicapai oleh madrasah. Kesiapan input sangat diperlukan agar proses dapat berlangsung dengan baik. Oleh karena itu, tinggi rendahnya mutu input dapat diukur dari tingkat kesiapan input. Makin tinggi kesiapan input, makin tinggi pula mutu input tersebut.

Proses pendidikan merupakan berubahnya sebuah sesuatu menjadi sesuatu yang lain. Sesuatu yang berpengaruh terhadap berlangsungnya proses disebut input, sedang sesuatu dari hasil proses disebut output. Dalam pendidikan Islam berskala mikro (tingkat madrasah), proses yang dimaksud adalah proses pengambilan keputusan, proses pengelolaan kelembagaan, proses pengelolaan program, proses belajar mengajar, dan proses monitoring dan evaluasi dengan catatan bahwa proses belajar mengajar memiliki tingkat kepentingan tertinggi dibandingkan dengan proses-proses lainnya.

Proses dikatakan bermutu apabila pengkordinasian dan penyerasian serta pemaduan input madrasah (guru, peserta didik, kurikulum, uang, peralatan, dan sebagainya) dilakukan secara harmonis, sehingga mampu menciptakan situasi pembelajaran yang menyenangkan (enjoyable learning), mampu mendorong motivasi dan minat belajar, dan benar-benar 
mampu memberdayakan peserta didik. Kata memberdayakan mengandung arti bahwa peserta didik tidak sekedar menguasai pengetahuan yang diajarkan oleh gurunya, akan tetapi pengetahuan tersebut juga telah menjadi muatan nurani peserta didik, dihayati, diamalkan dalam kehidupan seharihari, dan yang lebih penting lagi peserta didik tersebut mampu belajar secara terus menerus (mampu mengembangkan dirinya).

Output pendidikan merupakan kinerja madrasah. Kinerja madrasah adalah prestasi madrasah yang dihasilkan dari proses/perilaku madrasah. Kinerja madrasah dapat diukur dari kualitasnya, efektifitasnya, produktivitasnya, efisiensinya, inovasinya, kualitas kehidupan kerjanya, dan moral kerjanya. Khusus yang berkaitan dengan mutu output madrasah, dapat dijelaskan bahwa output madrasah dikatakan bermutu tinggi jika prestasi madrasah, khususnya prestasi belajar peserta didik menunjukkan pencapaian yang tinggi dalam: (1) prestasi akademik, berupa nilai ulangan umum, UN, karya ilmiah, lomba akademik; dan (2) prestasi non-akademik, seperti misalnya IMTAQ, kejujuran, kesopanan, dan kegiatan-kegiatan ekstrakurikuler lainnya. Mutu madrasah dipengaruhi oleh banyak tahapan kegiatan yang saling berhubungan (proses) seperti misalnya perencanaan, pelaksanaan, dan pengawasan.

Dengan demikian, madrasah bermutu terpadu sebagai bagian dari lembaga pendidikan Islam adalah penghasil jasa pendidikan yang diharapkan masyarakat untuk mewujudkan sumberdaya manusia yang berkualitas melalui sistem dan hasil pendidikan Islam yang bermutu (Novi Primiani dan Wahyu Ariani, 2005: 178).

\section{Langkah-Langkah Transformasi Menuju Madrasah Bermutu Terpadu}

Era globalisasi merupakan era persaingan mutu. Oleh karena itu lembaga pendidikan Islam harus memperhatikan mutu pendidikan Islam. Lembaga pendidikan Islam berperan dalam kegiatan jasa pendidikan maupun pengembangan sumber daya manusia harus memiliki keunggulan-keunggulan yang diprioritaskan dalam lembaga pendidikan Islam tersebut. Transformasi menuju madrasah bermutu diawali dengan mengadopsi dedikasi bersama terhadap mutu oleh dewan madrasah, kepala madrasah, dewan guru, staf, peserta didik, dan masyarakat. Kemudian proses transformasi tersebut dilanjutkan dengan memperhatikan hal pokok sebagai berikut: 
Pertama, perbaikan secara terus-menerus (continuous improvement). Konsep ini mengandung pengertian bahwa pihak pengelola madrasah senantiasa melakukan berbagai perbaikan dan peningkatan secara terus menerus untuk menjamin semua komponen penyelenggara pendidikan di madrasah telah mencapai standar mutu yang ditetapkan.

Kedua, menentukan standar mutu (quality assurance). Paham ini digunakan untuk menetapkan standar-standar mutu dari semua komponen yang bekerja dalam proses produksi atau transformsasi lulusan madrasah. Standar mutu madrasah misalnya dapat berupa pemilikan atau akuisisi kemampuan dasar pada masing-masing bidang pembelajaran.

Ketiga, perubahan kultur (change of culture). Konsep ini bertujuan membentuk budaya organisasi yang menghargai mutu sebagai orientasi semua komponen organisasional. Jika manajemen ini diterapkan di madrasah, maka pihak pimpinan madrasah harus berusaha membangun kesadaran para anggotanya mulai dari pemimpin sendiri, staf, guru, peserta didik, dan berbagai unsur terkait seperti pemimpin yayasan, orang tua, dan pengguna lulusan madrasah akan pentingnya mempertahankan dan meningkatkan mutu pembelajaran, baik mutu hasil maupun proses pembelajaran. Perubahan kultur ke arah kultur mutu ini antara lain dilakukan dengan menempuh cara-cara; perumusan keyakinan bersama, intervensi nilai-nilai keagamaan, yang dilanjutkan dengan visi dan misi madrasah.

Keempat, perubahan organisasi madrasah (upside-down organization). Jika visi dan misi serta tujuan madrasah sudah berubah atau mengalami perkembangan, maka sangat dimungkinkan terjadinya perubahan organisasi madrasah. Perubahan organisasi madrasah ini bukan berarti perubahan wadah organisasi madrasah, melainkan perubahan sistem dan struktur organisasi madrasah yang melambangkan hubungan-hubungan kerja struktur organisasi dan kepengawasan dalam organisasi. Perubahan ini menyangkut perubahan kewenangan, tugas-tugas, dan tanggung jawab. Misalnya dalam kerangka manajemen berbasis madarsah, struktur organisasi dapat berubah terbalik dibandingkan dengan struktur konvensional. Jika dalam struktur konvensional berturut-turut dari atas ke bawah (senior manager, midle manager, teacher, support staff), sedangkan struktur yang baru yaitu dalam struktur organisasi layanan, keadaannya berbalik dari atas ke bawah berturut-turut (learner, teacher, support staff, leader). 
Kelima, mempertahankan hubungan dengan pelanggan (keepping close to the customer). Madrasah sebagai organisasi pendidikan Islam menghendaki kepuasan pelanggan, maka madrasah perlu mempertahankan hubungan baik dengan pelanggan. Hubungan baik tersebut dikembangkan dalam unit public relations. Berbagai informasi antara madrasah dan pelanggan harus terus menerus dipertukarkan agar madrasah senantiasa dapat melakukan perubahan-perubahan atau improvisasi yang diperlukan terutama berdasarkan perubahan sifat dan pola tuntutan serta kebutuhan pelanggan. Pelanggan juga diperkenankan melakukan kunjungan, pengamatan, penilaian dan memberikan masukan kepada institusi madrasah. Semua masukan itu selanjutnya akan diolah dalam rangka mempertahankan dan meningkatkan mutu proses dan hasil-hasil pembelajaran. Kemudian yang perlu diperhatikan adalah bahwa dalam manajemen madrasah bermutu terpadu, guru dan staff justru dipandang sebagai pelanggan internal. Sedangkan peserta didik, orang tua, dan masyarakat termasuk pelanggan eksternal. Pelanggan internal maupun eksternal harus dapat terpuaskan melalui interval kreatif pimpinan institusi madrasah (Edward Sallis, $2006: 12$ ).

Keberhasilan transformasi menuju madrasah bermutu terpadu tidaklah mudah, diperlukan komitmen dan kerja sama yang baik antara stakeholeders pendidikan di madrasah. Untuk bisa menghasilkan madrasah yang bermutu, madrasah harus memperhatikan 14 prinsip Deming yang termasyhur yang merupakan kombinasi filsafat baru tentang mutu dan seruan terhadap manajemen untuk merubah pendekatannya. 14 prinsip yang harus diperhatikan tersebut antara lain :

- Tumbuhkan terus menerus tekad yang kuat dan perlunya rencana jangka panjang berdasarkan visi ke depan dan inovasi baru untuk meraih mutu.

- Adopsi filosofi baru, termasuk di dalamnya adalah metode baru dalam bekerja.

- Hentikan ketergantungan pada pengawasan jika ingin meraih mutu. Setiap individu yang terlibat karena sudah bertekad menciptakan mutu hasil produk/jasanya, ada atau tidak ada pengawasan haruslah selalu menjaga mutu kinerja masing-masing. 
- Hentikan hubungan kerja yang hanya atas dasar harga. Harga harus selalu terkait dengan nilai kualitas produk atau jasa.

- Selamanya harus dilakukan perbaikan-perbaikan terhadap kualitas dan produktivitas dalam setiap kegiatan.

- Lembagakan pelatihan sambil bekerja (on the job training) karena pelatihan adalah alat yang dahsyat untuk pengembangan kualitas kerja untuk semua tingkatan dalam unsur lembaga.

- Lembagakan kepemimpinan yang membantu setiap orang untuk dapat melakukan pekerjaan dengan baik, miasalnya : membina, memfasilitasi, membantu mengatasi kendala, dan lain-lain.

- Hilangkan sumber-sumber penghalang komunikasi antar bagian dan antar individu dalam lembaga.

- Hilangkan sumber-sumber yang menyebabkan orang merasa takut dalam organisasi agar mereka dapat bekerja secara efektif dan efisien.

- Hilangkan slogan-slogan dan keharusan-keharusan kepada staf. Hal seperti itu biasanya hanya akan menimbulkan hubungan yang tidak baik antara atasan dan bawahan atau lebih jauh akan menjadi penyebab rendahnya mutu dan produktivitas pada sistem organisasi, bawahan hanya bekerja sekedar memenuhi keharusan saja.

- Hilangkan kuota atau target-target kuantitatif belaka. Bekerja dengan menekankan pada target kuantitatif sering melupakan kualitas.

- Singkirkan penghalang yang merebut atau merampas hak para pimpinan dan pelaksana untuk bangga dengan hasil kerjanya masing-masing.

- Lembagakan program pendidikan dan pelatihan untuk pengembangan diri bagi semua orang dalam lembaga. Setiap orang harus sadar bahwa sebagai profesional harus selalu meningkatkan kemampuan dirnya.

- Libatkan semua orang dalam lembaga untuk ikut serta dalam proses transformasi menuju peningkatan mutu (Edward Sallis, 2006 : 100).

Setelah memperhatikan 14 prinsip pencapaian mutu Deming di atas, madrasah kemudian mentransformasikan dan mengaplikasikan prinsipprinsip tersebut sebagai berikut :

- Untuk menjadi madrasah yang bermutu terpadu perlu kesadaran, niat dan usaha yang sungguh-sungguh dari segenap unsur di dalamnya. Pengakuan orang lain (peserta didik, orang tua, dan masyarakat) bahwa madrasah kita adalah bermutu harus diraih. 


\section{Novan Ardy Wiyani}

- Madrasah yang bermutu adalah yang secara keseluruhan memberikan kepuasan kepada pelanggannya, artinya harapan dan kebutuhan pelanggan terpenuhi dengan jasa yang diberikan oleh madrasah tersebut. Kebutuhan pelanggan adalah berkembangnya SDM yang bermutu dan tersedianya informasi, pengetahuan dan teknologi yang bermanfaat.

- Perhatian madrasah selalu ditujukan pada kebutuhan dan harapan para pelanggan.

- Madrasah yang bernutu tumbuh dan berkembang serta bekerja sama dengan baik antar sesama unsur di dalamnya untuk mencapai mutu yang ditetapkan. Sebagai contoh, guru secara kelompok bekerjasama menyusun strategi pembelajaran peserta didik secara efektif dan efisien. Jika hanya satu atau dua saja guru yang mengajar secara baik tidaklah cukup, karena tidak akan menjamin terjadinya mutu peserta didik yang baik. Untuk itu, maka semua guru harus menjadi pengajar yang baik. Sebaliknya, jika guru menjadi pengajar yang baik maka peserta didiknya haruslah ingin belajar secara efektif. Proses belajar mengajar tidak dapat dikatakan efektif dan efisien jika hanya sepihak, gurunya saja atau peserta didiknya saja yang baik. Interaksi yang baik antar sesama unsur dalam madrasah harus terjalin secara intensif agar pencapaian mutu dapat berhasil sesuai harapan. Dalam upaya menggiatkan kerjasama antar unsur dalam madrasah tersebut perlu dibentuk tim perbaikan mutu yang diberi kewenangan untuk mencari upaya agar mutu madrasah lebih baik. Untuk itu, pelatihan kepada tim terutama tentang cara-cara bekerjasama yang efektif dan efisien dalam tim sangat diperlukan.

- Diperlukan pimpinan madrasah yang mampu memotivasi, mengarahkan, dan mempermudah serta mempercepat proses perbaikan mutu. Pimpinan madrasah bertugas sebagai motivator dan fasilitator bagi orang-orang yang bekerja di bawah pengawasannya untuk mencapai mutu. Setiap atasan adalah pemimpin sehingga ia haruslah memiliki kepemimpinan. Kepemimpinan haruslah yang membuat orang kemudian merasa lebih berdaya sehingga yang dipimpin mampu melaksanakan tugas pekerjaannya lebih baik dan hasil yang lebih baik pula. 
- Semua kinerja guru di madrasah harus selalu diorientasikan pada mutu karena setiap unsur yang ada di dalamnya telah berkomitmen kuat pada mutu. Akibat dari orientasi ini, maka semua kinerja yang tidak bermutu ditolak dan dihindari.

- Ada upaya perbaikan mutu madrasah secara berkelanjutan. Standar mutu yang ditetapkan sebelumnya selalu dievaluasi dan diperbaiki sedikit demi sedikit sesuai dengan kemampuan yang dimiliki.

- Segala keputusan untuk perbaikan mutu layanan pendidikan di madrasah selalu didasarkan data dan fakta untuk menghindari adanya kelemahan dan keraguan dalam pelaksanaannya.

- Penyajian data dan fakta dapat ditunjang dengan berbagai alat dan teknik untuk perbaikan mutu yang bisa dianalisis dan disimpulkan sehingga tidak menyesatkan.

- Hendaknya pekerjaan di madrasah jangan dilihat sebagai pekerjaan rutin yang sama saja dari waktu ke waktu karena bisa membosankan. Setiap kegiatan di madrasah harus direncanakan dan dilaksanakan dengan cermat, serta hasilnya dievaluasi dan dibandingkan dengan standar yang ditetapkan. Hendaknya tercipta kondisi pada setiap yang bekerja di madrasah untuk bersedia belajar sambil bekerja dan sedapat mungkin diprogramkan baik belajar tentang materi, metode, prosedur, dan lain-lain.

- Dari waktu ke waktu prosedur kerja yang digunakan di madrasah perlu ditinjau apakah mendatangkan hasil yang diharapkan. Jika tidak, maka prosedur tersebut perlu diiubah dengan yang lebih baik.

- Perlunya pengakuan dan penghargaan bagi yang telah berusaha memperbaiki mutu kerja dan hasilnya. Guru dan staf mencoba cara kerja baru, jika mereka berhasi diberi pengakuan dan penghargaan.

- Perbaikan prosedur antar fungsi di madrasah sebagai bentuk kerjasama harus dijalin hubungan saling membutuhkan satu sama lain. Tidak ada yang lebih penting satu unsur dari unsur yang lain dalam mencapai mutu madrasah. Misalnya tenaga administrasi sama pentingnya dengan tenaga pengajar, dan sebaliknya.

- Madrasah mentradisikan pertemuan antar guru dan peserta didik untuk mereview proses belajar mengajar dalam rangka memperbaiki layanan pendidikan yang bermutu. Pertemuan dengan orang tua peserta didik, 
masyarakat dan alumni dapat dilakukan oleh madrasah. Pendek kata, hendaknya semua unsur yang berkepentingan dengan madrasah berpartisipasi ikut mengembangkan madrasah mencapai mutu yang baik.

\section{Penutup}

Mendasarkan pada pembahasan di atas, tampak bahwa sebenarnya mutu pendidikan Islam merupakan akumulasi dari semua mutu jasa pelayanan yang ada di lembaga pendidikan Islam yang diterima oleh para pelanggannya. Madrasah sebagai salah satu dari lembaga pendidikan Islam memberikan layanan pendidikan melalui proses yang panjang dan kegiatannya yang satu dipengaruhi dengan kegiatan yang lain. Bila semua kegiatan dilakukan dengan baik, maka hasil akhir layanan pendidikan yang dilakukan oleh madrasah tersebut akan mencapai hasil yang baik berupa "mutu terpadu.

\section{Daftar Pustaka}

Arif, Mahmud. (2010). Sketsa Sejarah, Geliat, dan Dinamika Peran Madrasah dalam Merespon Tantangan Pendidikan Islam : Dilema Madrasah dalam Kancah Pendidikan dan Peran Kontributif Madrasah Berbasis pesantren (MBP), Jurnal Antologi Pendidikan Islam, Yogyakarta

Arcaro, S Jerome. (2009). Pendidikan Berbasis Mutu : Prinsip-prinsip Perumusan dan Tata Langkah Penerapan, diterjemahkan oleh Yosai Irianta, Yogyakarta: Pustaka Pelajar

Danim, Sudarwam (2008). Visi Baru Manajemen Sekolah : Dari Unit Birokrasi ke Lembaga Akademik, Jakarta: Bumi Aksara

Mulyasa E. (2009). Kurikulum Tingkat Satuan Pendidikan: Suatu Panduan Praktis, Bandung : Remaja Rosda Karya

Nuryatno, M. Agus. (2010). Isu-isu Kritis dalam Pendidikan Islam: Perspektif Pedagogik Kritis, Jurnal Hermenia, Volume 9, Nomor 2

Primiani, Novi dan Ariani, Wahyu (2005). Total Quality Management 
dan Service Quallity dalam Organisasi Pendidikan Tinggi, Jurnal Cakrawala Pendidikan

Saleh, Abdul Rachman, Madrasah dan Pendidikan Anak Bangsa : Visi, Misi, dan Aksi, Jakarta : Raja Grafindo Persada, 2004

Sallis, Edward. (2008) Total Quality Management in Education, Yogyakarta: IRCiSod

Sukmadinata, Nana Syaodih, dkk. (2006). Pengendalian Mutu Pendidikan Sekolah menengah: Konsep,Prinsip, dan Instrumen, Bandung: Refika Aditama

Sutrisno. (2010). Mengingat Kembali Jiwa Pendidikan Sebagai respon Terhadap Globalisasi, Jurnal Hermenia, Volume 9, Nomor 2

Tilaar, H.A.R (2000). Paradigma Baru Pendidikan Nasional, Jakarta: Rineka Cipta 